\title{
Kids Into Health Careers: A Rural Initiative
}

\author{
Lori S. Lauver PhD \\ Thomas Jefferson University \\ Beth Ann Swan PhD \\ Thomas Jefferson University \\ Margaret Mary West PhD \\ Thomas Jefferson University \\ Ksenia Zukowsky PhD \\ Thomas Jefferson University \\ Mary Powell PhD \\ Thomas Jefferson University
}

Follow this and additional works at: https://jdc.jefferson.edu/nursfp

See next page for additional authors

Part of the Nursing Commons

Let us know how access to this document benefits you

\section{Recommended Citation}

Lauver PhD, Lori S.; Swan PhD, Beth Ann; West PhD, Margaret Mary; Zukowsky PhD, Ksenia;

Powell PhD, Mary; Frisby PhD, Tony; Neyhard MA, Sue; and Marsella BA, Alexis, "Kids Into Health Careers: A Rural Initiative" (2010). College of Nursing Faculty Papers \& Presentations. Paper 32. https://jdc.jefferson.edu/nursfp/32

This Article is brought to you for free and open access by the Jefferson Digital Commons. The Jefferson Digital Commons is a service of Thomas Jefferson University's Center for Teaching and Learning (CTL). The Commons is a showcase for Jefferson books and journals, peer-reviewed scholarly publications, unique historical collections from the University archives, and teaching tools. The Jefferson Digital Commons allows researchers and interested readers anywhere in the world to learn about and keep up to date with Jefferson scholarship. This article has been accepted for inclusion in College of Nursing Faculty Papers \& Presentations by an authorized administrator of the Jefferson Digital Commons. For more information, please contact: JeffersonDigitalCommons@jefferson.edu. 


\section{Authors}

Lori S. Lauver PhD, Beth Ann Swan PhD, Margaret Mary West PhD, Ksenia Zukowsky PhD, Mary Powell $\mathrm{PhD}$, Tony Frisby PhD, Sue Neyhard MA, and Alexis Marsella BA 
As submitted to:

\title{
The Journal of Rural Health
}

And later published as:

\section{Kids Into Health Careers: A Rural Initiative \\ Volume 27, Issue 1, pages 114-121, Winter 2011 \\ DOI: $10.1111 /$ j.1748-0361.2010.00316.x}

Lori S. Lauver, PhD;1 Beth Ann Swan, PhD;2 Margaret Mary West, PhD; 1 Ksenia Zukowsky, PhD;2 Mary Powell, PhD;2 Tony Frisby, PhD;3 Sue Neyhard, MA; 1 \& Alexis Marsella, BA2

1 Thomas Jefferson University, Jefferson School of Nursing, Danville, Pennsylvania

2 Thomas Jefferson University, Jefferson School of Nursing, Philadelphia, Pennsylvania

3 Thomas Jefferson University, AISR Education Services, Philadelphia, Pennsylvania

\begin{abstract}
Purpose: To describe a project that introduces middle school and high school students living in Pennsylvania's rural geographic regions to nursing careers through outreach extended to students regardless of gender, ethnicity, or socioeconomic status.

Method: The authors employed many strategies to inform students about careers in nursing. The methods included: working with guidance counselors, participating in community health fairs, taking part in school health career fairs, collaborating with Area Health Education Centers, serving on volunteer local education advisory boards, developing a health careers resource guide, and establishing a rural health advisory board.
\end{abstract}

Findings: Developing developmentally appropriate programs may have the potential to pique interest in nursing careers in children of all ages, preschool through high school. Publicity is needed to alert the community of kids into health care career programs. Timing is essential when 
planning visits to discuss health care professions opportunities with middle and high school students. It is important to increase the number of high school student contacts during the fall months. Targeting high school seniors is particularly important as they begin the college applications process and determine which school will best meet their educational goals.

Conclusions: Outcome measures to determine the success of health career programs for students in preschool through high school are needed. Evaluation methods will be continued over the coming years to assess effectiveness.

Key words kids into health careers, nursing shortage, recruitment strategies, rural.

The Kids into Health Careers (KIHC) Initiative established by the Jefferson School of Nursing (JSN) was implemented with students in rural Pennsylvania communities. The KIHC Initiative is a component of a larger project funded by the Department of Health and Human Services, Health Resources and Services Administration, Bureau of Health Professions (BHPR) Division of Nursing in which the JSN provides its nursing education programs via a distance learning format to nurses residing and working in rural communities. Although the overall goal of the grant is to increase numbers of advanced practice nurses (APNs) in rural Pennsylvania, educating nurses for advanced nursing practice can be challenging given the overall shortage of registered nurses (RNs). Nurse shortages exist throughout the United States with the demand exceeding today's supply, and shortages are expected to continue well into the future. A shortfall of 260,000 RNs across the United States is anticipated by 2025.1 Likewise, Pennsylvania's shortage of 6,400 RNs in 2006 is expected to increase to 38,000 RNs in 2016.2

Approximately $28 \%$ of Pennsylvania's citizens live in rural counties. However, the state's rural counties have fewer rates of RNs employed in health care (5.58 per 1,000 population) compared to urban counties (8.14 per 1,000 population). 3 Moreover, recent data show only $8 \%$ of Pennsylvania RNs work in rural communities.4 It is the nurse who delivers, coordinates, and directs the care of patients in hospitals, clinics, and physician offices and the APN who fills the gap in primary care.5 Consequently, educating APNs can be a 2-tier balancing act given the shortage of professional RNs living and working in rural areas. The nurse shortage must be alleviated, or at the least, held at bay while simultaneously encouraging seasoned nurses to pursue advanced practice nursing education and careers. 
More than $\mathbf{4 0}$ years ago the US Congress recognized the disparity in supply and distribution of health care professionals between rural and urban areas. As a result, in 1971, legislation was drafted to address health care access issues and to support the development of a National Area Health Education Center (AHEC). The overall mission of AHECs is to enhance access to quality health care, particularly primary and preventative care, by improving the supply and distribution of health care professionals through community and academic partnerships.6 Currently, 54 AHEC programs and 208 AHEC centers in 47 states including Pennsylvania are supported by this early legislation. As the dearth of primary health care providers persists in rural areas, AHECs continue to seek ways to alleviate the shortage by looking to increase numbers of physicians, APNs, and RNs.

The BHPR created a KIHC Initiative in 2002 to encourage children to consider careers in nursing and other health professions in response to the nursing shortage crisis and future health care demands.7 While also targeting guidance counselors, teachers, and administrators, and members of other professional organizations, an additional component was to inform minority and socioeconomically disadvantaged students in middle and high school (and their parents), about 4 major points. First, health care job opportunities exist; second, financial aid is available to pursue education in health care related fields; third, careers in health care fields are personally rewarding; and last, working in health care fills a critical need for underserved and disadvantaged people.7 Since 2002, varied strategies have been developed and implemented to expose children to and gain their interest in health care careers.

Given the RN shortage and keeping the BHPR's 4 major points in mind, the aim of our project was to introduce children living in Pennsylvania's rural geographic regions to nursing careers. Outreach extended to all children regardless of gender, ethnicity or socioeconomic status, and we included all age groups from preschool to high school.

\section{Literature Review}

The literature shows that identifying strategies to recruit young people into health careers is important in alleviating shortages. A variety of approaches have been identified that focus on providing information to middle and high school students about careers in the health professions. Some involve participation in community festivals by using health and nursing career booths to promote health careers; others include 
networking with local middle and high schools.8 Gaining access to inschool activities and students often requires collaboration with school nurses and guidance counselors. Success also may depend upon working with school nurses to ensure ageappropriate education materials and/or with guidance counselors to identify preferences for dissemination of health career information.9

Because guidance counselors are in close proximity to teenagers, they have the ability to influence decision-making and career choices. It is important for schools of nursing to provide career information to school counselors about the nursing role, nursing careers, and student attributes essential for success. 10 Having this information can help guidance counselors to encourage student interest in nursing careers. Moreover, implementing a guidance counselor education program that focuses on career paths in nursing can provide counselors with the information needed to help promote nursing as a viable career option. 11

More recently, nursing and health professions exploration summer camps have become venues to inform high school students about health careers. Camps are typically held by universities or hospital health systems.

Regardless of sponsorship, summer camps offer participants the ability to shadow various health professionals for a more intensive look at the dayto-day work of health care providers. Camp attendees may interact with nursing students, as well as nurses in a variety of settings, and participate in hands-on experiences, such as taking part in a mock code, touring trauma helicopters, attending CPR, as well as participating in simulation experiences. 12 Participants also tour area colleges and health care facilities, learn about the college application and financial aid process, and how to develop a resume and interviewing skills. By participating in summer camp, students have a chance to learn more about themselves and to see which health career opportunities are a good fit. Summer camps held by universities have an added benefit in that they can serve as a recruitment tool. 13 Students housed in dormitories have the ability to experience university life and get to know department faculty.

A new model to promote careers in nursing is the formation of partnerships between local universities and school districts, thus encouraging students to explore the role of nursing in health care. These partnerships create opportunities for select high school students to participate in nurse shadowing opportunities and gain experiential knowledge about nursing. By bridging the gap between perceptions and real world nursing, students have a better understanding about the role and responsibility of the nurse, which may positively influence career decision making and nursing as a career choice. 14 
The recruitment of middle-school-age children, those in grades 6-8, into health careers has gained interest in the last several years. In particular, nurse leaders and workforce strategists have advocated for the recruitment of middle school students into nursing. The argument for recruiting this age group of children is well founded since middle school students are beginning career exploration and are developmentally open to a variety of choices. Because academic and career goals are well established by the high school years, it is presumed that nursing probably will not be viewed as a viable career option if this window of opportunity between the eighth and ninth grades is overlooked. 15 Consequently, greater effort toward targeting this group into health careers and nursing is advocated. One creative recruitment strategy implemented by Duncan Hospital in Duncan, Oklahoma, promotes health education and prevention of illness for adolescents, and clinical interaction between adolescent students and hospital staff, in particular nurses. 16

A new idea recently emerging to combat the future nursing shortage is the recruitment of young children into nursing careers. Some nursing professionals believe it is never too early to encourage children to become nurses, and positively influencing children's perceptions about nursing should occur during the preschool and elementary school years. In fact, reaching out to children in the second grade is now suggested since this is the time when children begin to dream about what they will be when they grow up. 17 Ideas to influence preschool-age and schoolage children's perceptions include the modeling of healthy behaviors by nurses and nursing students and encouraging young children to participate in healthy activities such as hand washing, sun safety, and choosing healthy snacks. 18 While these novel ideas of recruiting young children have potential to influence nursing as a career choice, data is not yet available to show the success of recruitment at such a young age. The usefulness of these creative strategies requires future evaluation.

Minority populations remain an untapped group that schools of nursing are targeting. 19 Historically, these groups have been reluctant to consider a nursing career because of preconceived notions and misconceptions about the profession. For example, male high school students perceive nursing as women's work and believe it is not macho to be a nurse.20 Moreover, other underrepresented groups such as Hispanics and blacks view nursing as a career that lacks prestige and upward mobility. Given the many career paths nursing has to offer, emphasizing good income, status, and upward mobility are important points to be made.21

Description of Geographic Region and Population Targeted 
Geographically, Pennsylvania comprises 67 counties of which 48 are rural and 19 are urban, and 501 public school districts of which 243 are rural and 258 are urban. A county or school district is classified as rural when the number of persons is fewer than $\mathbf{2 7 4}$ per square mile within the county or school district.22 The grant and the KIHC initiative initially targeted 19 rural and 3 urban counties. Examination of US Census data shows that the average per capita income of Pennsylvania rural counties in 2007 was $\$ 28,950$ which is approximately $25 \%$ less than the per capita income of $\$ 38,793$ for the state.23 A comparison of median household income between rural households and urban households shows an average household income in rural Pennsylvania homes of $\$ 52,688$ or approximately $23 \%$ less than the median urban household income of $\$ 68,114.24$

\section{Our Approach}

Using the literature as a beginning point, the rural team began outreach by becoming involved in local high school and middle school health and career fairs within a 25-mile radius of the JSN rural site in Danville, Pennsylvania. Given the difficulty with gaining entree into school systems, we quickly discovered the need for a multifaceted approach, and subsequently, we collaborated with a variety of leaders in both private and public organizations to find ways to meet our objectives. This collaboration resulted in the creation of a Rural Health Advisory Board whereby members serve as strategic advisors to facilitate development of our education, practice, and research agendas, as well as the KIHC initiative. Advisory Board members meet twice a year as a group via conference call. As ideas emerge in the group, additional meetings are set up between board members and grant team individuals. Members of the Rural Health Advisory Board include educators, researchers, clinicians, policy makers, health regulators, managed care administrators, state and local health department officials, school superintendents, and elected state officials. Over the first 2-year period, new ideas about recruiting $\mathrm{KIHC}$, as well as organizations that could provide additional assistance, were shared by Advisory Board members. Gradually, we were able to gain access to school children beyond our immediate sphere of influence and into school systems in more distant counties targeted by the grant. Notably, without the insight of Advisory Board members, opportunities to promote KIHC would have been missed, and our program would not have been as successful. Moreover, as we approached year 3 , the Advisory Board remained active, offering suggestions and new ideas as we evaluated the effectiveness of earlier strategies. 
Board members also provided referrals to supporting agencies, which had a snowball effect whereby one contact led to another, and it improved our outreach to groups and communities for which we may not have been granted access. For example, one member of the board suggested networking with Pennsylvania AHECs to promote our KIHC initiative. This member provided a handbook titled Resource Guide to Healthcare Options in Pennsylvania-Children, Adults, and Seniors, 25 which offered useful information about low-cost and no-cost health care resources, and in particular the contact information needed for AHEC and its directors. The outcomes of collaboration with Pennsylvania AHECs will be discussed later in the section describing year 2.

Similarly, another Advisory Board member from West Virginia suggested participating in Pennsylvania's State Guidance Counselor Association. Additional information about the Pennsylvania School Counselor Association (PSCA) can be found at http://www.psca-web.org/.26 Drawing on his experience, we identified 2 areas to facilitate our project. First was to join the PSCA and second, to develop a Pennsylvania Health Care Career Handbook, both of which will be discussed later in the section outlining our plans for year 3 . Table 1 highlights the activities in which we participated in years 1 and 2 of the grant.

\section{Year 1}

To prime the pipeline for future careers in nursing and support an effective nursing workforce and health care system, the rural team's first project began by reaching out to organizations already instituting programs that encourage and help students plan careers in nursing and which were becoming visible to the public. In year 1 , a faculty member from the rural campus and a recruiting specialist participated in a hospital nursing expo that brought together nurses from a local hospital with high school students to showcase nursing opportunities. Simulation strategies to emulate specialty fields in nursing such as operating room nursing gave students opportunities for hands-on participation. In addition to interacting with potential health career students, an important aspect of this event was networking with several high school guidance counselors from the local area who were unfamiliar with the different types of nursing education programs and the coursework students should undertake in high school when desiring to pursue a health care or nursing career. Beginning relationships with these individuals promoted entry into the respective school system and additional networking with students, guidance counselors, and teachers to further discuss health care careers and, in particular, all levels of nursing careers. 
In addition, the team participated in a multi-county health/career fair and an area community hospital children's health fair. While our goal was to engage children in healthy activities and provide information to children about health care careers, an unexpected and extremely positive result was the interest that parents showed in learning more about health care careers not only for their children but for themselves. While some parents were interested in beginning a career in nursing, others were interested in nursing as a second career. Subsequently, parents provided the team with contact information, and the additional information about JSN programs was provided via follow-up telephone calls.

One member of the grant team and an instructor teaching in the JSN Associate of Science Degree in Nursing (ASN) program located at the rural site also participated in a local university-based health fair. This liberal arts university does not offer a program of study in nursing or any allied health career, although it does offer a premed major. Entry was obtained by networking with the university's health nurse who also had ties to a middle school within the same county. By helping to meet the needs of the college health nurse in charge of the university health fair, we were able to gain entry into a local middle school to participate in the annual middle school health fair.

During the university health fair, information about healthy behaviors was provided to students. Those students interested in a health care career were provided with additional information about careers in nursing and allied health. One goal was to show nursing as a viable career choice for those students completing a liberal arts degree and who are uncertain about a future career path. Students completing a current program of study were encouraged to consider nursing as a second degree with emphasis placed on nursing education programs having an accelerated program of study for those individuals with a college degree. This seconddegree focus was important to us in our endeavor to extend our relationship with community leaders and develop and continue positive relationships with the university.

\section{Year 2}

Brochures promoting KIHC resources were created for use at health and career fairs during the second year of the grant. The team's activities for year 2 took us to 2 health fairs sponsored by local community hospitals and located in shopping malls in 2 different counties. Our visibility at a store noted for pre-teen and teenage activity yielded 950 participant contacts with 26 requests for specific information about JSN. Over a 9month period we networked with a variety of high schools and middle 
schools to participate in health fairs and college career fairs. Twenty-two middle and high schools in 15 rural counties were visited, with school nurses and guidance counselors providing entry into the school systems. Approximately 1,756 middle school and high school students were reached in the 22 schools throughout the school year.

Two additional opportunities to talk to children about health care careers were presented to our recruitment specialist. These venues included a youth seminar sponsored by the Lions Club and a hospital expo for children in pre-kindergarten through second grade in 2 other counties. We availed ourselves of both opportunities and captured the attention of an additional 565 youth and their parents.

At the request of the school nurse at one high school participating in our effort to promote health care careers to students in her school system, a faculty member at our rural campus participated on a high school Health Professions Advisory Board committee. Organized and led by the high school nurse, the Board was formed with the sole purpose of developing a health professions education curriculum, which would encompass grades 9 to 12, and better prepare high school students for entry into college as health professions majors. The role of the board was to identify courses essential for preparation into collegiate health professions majors, develop criteria for student admission into the health professions education track, formulate policy including absenteeism and dress code, develop then evaluate student applications for admission into the program, and facilitate student clinical placement with a variety of health profession businesses and organizations.

The outcome of serving on the board was acceptance of 15 exceptionally qualified students into the high school health professions career curriculum for the academic 2009-2010 year and an invitation for the JSN to continue participation in the high school's student careers recruitment fair. A second outcome is that the local university intends to accept more students living locally into its health professions programs since they will be better prepared for entry into health professions majors. It is likely these health profession graduates will choose to live and practice in the community in which they grew up, thus increasing the supply of health care providers in the local area. Participation is ongoing since the board is responsible for assessment and evaluation of program goals and objectives, and making recommendations for program change.

Year 2 of the grant also yielded collaboration with 3 of 7 Pennsylvania AHECs (Eastcentral, Northcentral, Northeast) and the sharing of ideas and forming partnerships to promote KIHC activity outreach. We found that the 
Pennsylvania AHEC program, established in 1994, has a 3-fold mission. First, it is to connect students to health care careers; second, to connect professionals to communities; and third, to connect communities to better health,27 which dovetailed with the goals of our KIHC initiative.

Our approach to meeting AHEC program directors was via e-mail introduction. Initially, we received 1 positive e-mail response. Establishing initial rapport with 1 AHEC program director led to access to 2 additional AHEC programs. Appointment times and locations were scheduled at the convenience of each of the AHEC directors. Our purpose in meeting with the directors was to learn more about the role of AHECs in the community served, then provide information about the JSN grant, the KIHC program, JSN and its programs, and finally if appropriate, determine interest in working together.

We found that community programs differed among AHECs based on the communities they served and how well the goal of our KIHC initiative was congruent with, did not duplicate, and dovetailed nicely with the overall purpose and goals of each center. Thus, the AHEC directors and their assistants willingly helped to identify venues to promote our initiative. For example, the Northeast Pennsylvania AHEC director distributed KIHC and JSN materials to middle and high school guidance counselors within his or her region. Since the NE Pennsylvania AHEC serves 9 rural counties (Bradford, Lackawanna, Luzerne, Monroe, Pike, Sullivan, Susquehanna, Wayne, and Wyoming) of which 3 (Monroe, Pike, and Sullivan) are targeted by the JSN KIHC project, an added benefit was that outreach extended to 6 additional rural counties. Other opportunities included a JSN link that was added to the Northeast Pennsylvania AHEC website and contact information for Health Occupational Students of America (HOSA), which is a national and statebased organization that promotes careers in health care. Information about Pennsylvania HOSA can be found at http://www.pahosa.org/.27

The Eastcentral Pennsylvania AHEC serves 5 counties (Berks, Carbon, Lehigh, Northampton, and Schuylkill), 2 of which included in the grant are classified as urban (Berks and Lehigh) and 1 rural (Schuylkill). We met with the Eastcentral AHEC director and were invited to provide JSN and KIHC career materials to be used at the Pennsylvania TEACH program, which was yet another avenue to promote KIHC activities to teaching professionals. A vice president of nursing from a local hospital in a nearby community also attended the meeting, inviting us to participate in the local hospital's health fair. Availing ourselves of this opportunity, we provided children of all ages an interactive healthy behavior learning experience and their parents information about KIHC. We also explored 
future participation in a health careers summer camp which will be sponsored by the Eastcentral Pennsylvania AHEC. Moreover, future avenues to reach out to minority populations, specifically Hispanic and African American women's groups, were explored since attracting minority students to health care fields is important.

The Northcentral AHEC serves communities in 10 Pennsylvania counties. Eight of these counties (Clinton, Columbia, Mifflin, Montour, Northumberland, Snyder, Tioga and Union) are rural; the other 2 (Lycoming and Centre) are urban. Seven of the rural counties and 1 of the urban counties were a part of the grant, extending our outreach by 2 additional counties. Meeting with the Northcentral program director yielded outreach opportunities similar to those provided by other AHEC directors, including adding a JSN link on their website. In addition, contact information for the Central Pennsylvania Workforce Development Board was provided since this board also promotes health career outreach.

Finally, 2 JSN faculty members attended the April 16, 2009, Pennsylvania Rural Health Association third legislative briefing, Rural Health in Pennsylvania: Issues, Perspectives, and Answers.28 The briefing afforded us the opportunity to hear testimony about the needs of rural communities, and in particular, health profession workforce shortages. Hosted by Pennsylvania Representative Kerry Benninghoff from the 171st District, a main point made to attendees was "the need to recruit more kids into health careers with a focus at the middle school grade level." While we did not provide testimony about our KIHC efforts, our work with children of all ages was publicly acknowledged by an AHEC program director.

\section{Year 3}

Our plan for the KIHC Initiative in year 3 of the grant included continuing past relationships with partners such as health care organizations/hospitals and AHECs, and developing new relationships with other organizations such as Pennsylvania HOSA and 4-H (head, heart, hands, health), a youth development education program in Pennsylvania. Since the remaining counties outlined in the grant fall within the purview of Southcentral and Northwest AHECs, we planned to pursue relationships with those centers. We also planned to continue our work with middle and high school guidance counselors, parents, and students both formally and informally. As an associate member of Pennsylvania's State Guidance Counselor Association, we planned to participate in the annual regional guidance counselor conference to be held in summer 2010. Lastly, with the assistance of the Advisory Board, we planned to develop a nursing and nursing-related careers handbook as a resource for those 
seeking information about nursing and nursing-related careers in Pennsylvania.

\section{Lessons Learned}

Although we initially targeted 22 rural counties identified in the grant to begin our KIHC activities, we found that other rural counties, as well as counties classified as urban, could benefit from our initiative. Given the high unemployment rate and lack of industry within those counties, it was important to extend our outreach. We participated in several middle and high school career fairs, receiving positive feedback from teachers, guidance counselors, students, and parents. The outcome of these fairs was 174 students showing interest in nursing as a career and requesting additional information about both ASN and BSN programs of study. Followup phone calls and in some cases application materials, as well as referrals to other colleges or universities, were provided by our recruitment specialist and were important adjuncts to our outreach.

Another lesson learned is the importance of informal networking. Gaining entry to health fair activities, middle schools and high schools required interacting with teachers and parents of middle school and high school students outside the formal school setting and showing enthusiasm for kidsinto health care career activities. Being visible and attending middle school and high school athletic events and music events was one way to open doors. Being accessible via phone or in person whether in the office or at home also served to establish relationships. Moreover, being passionate about nursing careers helped students, parents, teachers, and community members view nursing as a viable career option.

Media attention for the events we participated in sometimes was overlooked. Although we maintained a record of the KIHC activities for annual grant reporting purposes, we did not always publicize activities in local media sources such as newspapers. On some occasions, the middle or high school in which the health or career fair was held published the events in the student-parent newsletter. Given the high-profile nature of some community health activities sponsored by health care organizations at local shopping malls, some events were publicized in local newspapers. In retrospect, more media attention could have been sought for our KIHC activities.

\section{Recommendations}

A paucity of literature regarding the influence of promoting nursing careers on preschool and elementary school age children exists. 
Developing developmentally appropriate programs may have the potential to pique interest in nursing careers in children at an early age. Consequently, we believe it is important to reach out to preschool and elementary school age children and promote kids into health careers with these age groups using developmentally appropriate strategies and also identify ways to determine the success of such programs. Publicity is needed to alert the community of kids into health care career programs. Moreover, local media attention including pictures and articles about the KIHC activities held within the community should be solicited.

Timing is essential when planning visits to discuss health care professions opportunities with middle and high school students. It is important to increase the number of high school student contacts during the fall, particularly for those students who are juniors or seniors in high school. Targeting high school seniors is particularly important as they begin the college applications process and determine which school will best meet their educational goals. Expanding the KIHC career focus to freshman and sophomore students as well as those students in middle school should occur during the spring. This would provide freshmen and sophomores who do not have access to a specific health professions career high school curriculum to select courses in the academic curriculum that support a career in a health profession. Access to middle school students is more easily gained when middle school teachers and counselors are planning career day activities and student health fairs.

Lastly, little is known about the effect of KIHC promotion activities on middle school age students' career choices. Thus, outcome measures to determine the success of health career programs for this student group are needed. Evaluation methods will be continued over the coming years to assess effectiveness.

\section{References}

1. Buerhaus PI, Auerbach DI, Staiger DO. The recent surge in nurse employment: causes and implications. Health Aff. 2009;28(4):w657-w668.

2. Health Alliance of Pennsylvania. Facts about Pennsylvania's Registered Nurse Workforce. Available at: http://www.haponline.org/downloads/HAP Facts About Pennsylvania Registered Nurseworkforce March2009. pdf. Accessed November 11, 2009.

3. Health Professions Study Group. White Paper: The Nurse Workforce in Pennsylvania. Harrisburg, Pennsylvania: Pennsylvania Department of Health. 2004. Available at: 
http://www.dsf.health.state.pa.us/health/lib/health/ship/nursewhitepaper. pdf. Accessed August 22, 2009.

4. State Health Improvement Plan. Special Report on the Characteristics of the Pennsylvania Nurse Population in Pennsylvania. Updated August 2008. Available at: http://www.dsf.health.state.pa.us/health/lib/health/ 2008 RN Report Final.pdf. Accessed November 30, 2009.

5. Rother J, Lavizzo-Mourey R. Addressing the nursing workforce: a critical element for health reform. Health Aff . 2009;28(4):w620-w624.

6. National AHEC Organization. National Area Health Education Center Organization. Available at:

http://www.nationalahec.org/home/index.asp. Accessed December 21, 2009.

7. US Department of Health and Human Services, Health Resources and Services Administration, Bureau of Health Professions. Kids Into Health Careers. Available at: http://www.bhpr.hrsa.gov/kidscareers/. Accessed July 3, 2009.

8. Cohen R, Burns K, Frank-Stromborg M, Flanagan MS, Askins DL, EhrlichJones $L$. The kids into health care initiative: innovative approaches to help solve the nursing shortage. J Nurs Educ. 2006;45(5):186-189.

9. Matutina RE. Recruiting middle school students into nursing. J Sch Nurs. 2008;24(3):111-115.

10. Bolan C, Grainger P. What do high school guidance counselors really think of nursing? J Nurs Educ. 2005;44(3):135-138.

11. Campbell-Heider N, Sackett K, Whistler MP. Connecting with guidance counselors to enhance recruitment into nursing of minority teens. $J$ Prof Nurs.2008;24(6):378-384.

12. Drenkard K, Swartout E, Mill S. Nursing exploration summer camp: improving the image of nursing. J Nurs Adm. 2002;32(6):354-362.

13. Clusky M, Jackson J, Brubaker C, Cram E, Awl C. A university model for recruiting high school students into nursing. Nurs Educ Perspect.

2006;27(6);324-326.

14. Porter G, Edwards $P$, Granger B. Stagnant perceptions of nursing among high school students: results of a shadowing intervention study. $J$ Prof Nurs. 2009;25(4):227-233. 
15. Cohen R, Palumbo MV, Rambur B, Mongeon J. Middle school students' perceptions of an ideal career and a career in nursing. $J$ Prof Nurs. 2004;20(3):202-210.

16. Murer CG. Kids get their hands on health: Duncan regional hospital offers kids a unique experience. Rehab Manag. 2009;22(2):38-40. Available at: http://www.rehabpub.com/issues/articles/2009-03 08.asp. Accessed September 16, 2009.

17. Gilchrist KL, Rector, C. Can you keep them? Strategies to attract and retain nursing students from diverse populations: best practices in nursing education. J Transcult Nurs. 2007;18(3):277-285.

18. Nevidjon B, Erickson J. The nursing shortage; solutions for the short and long term. Online J Issues Nurs. 2001;6(1):16-35.

19. American Association of Colleges of Nursing. Effective Strategies for Increasing Diversity in Nursing Programs. Washington, DC: American Association of College of Nursing. December 2001. Available at: http://www.aacn.nche.edu/Publications/issues/dec01.htm. Accessed September 16, 2009.

20. Yurkovich $D$. Where the boy's aren't: gender disparity and the nursing profession. MODRN Nurs Mag. 2006;August-September:26-31.

21. Buerhaus PI, Donelan K, Norman L, Dittus R. Nursing students' perceptions of a career in nursing and impact of a national campaign designed to attract people into the nursing profession. $J$ Prof Nurs. 2005;21(2):75-83.

22. The Center for Rural Pennsylvania. Rural/Urban PA. Available at: http://www.ruralpa.org/rural urban.html. Accessed November 20, 2009.

23. Bishaw A, Semega J. US Census Bureau, American Community Survey Reports, ACS-09, Income, Earnings, and Poverty Data From the 2007 American Community Survey. Washington, DC: US Government Printing Office; 2008. Available at: http://www.census.gov/prod/2008pubs/acs09.pdf. Accessed November 21,2009.

24. The Center for Rural Pennsylvania. About rural PA. Available at: http://www.ruralpa.org/about.html. Accessed November 20, 2009. 
25. The Pennsylvania Office of Rural Health. Resource Guide to Healthcare Options in Pennsylvania. Children, Adults and Seniors. (3rd ed.). University Park, PA: Penn State University; 2008. Available at:

http://www.porh.psu.edu/publications/2009/low\%20cost.no\%20cost.july.0 8.final.with.cover.pdf. Accessed September 16, 2009.

26. Pennsylvania School Counselors Association. Available at: http://www.psca-web.org. 2007. Accessed September 1, 2009.

27. Health Occupational Students of America (HOSA). Available at: http://www.pahosa.org/. Accessed December 21, 2009. 28. Pennsylvania Rural Health Association. Third Legislative Briefing. Rural Health in Pennsylvania: Issues, Perspectives, and Answers. Harrisburg, PA; April 16, 2009. Available at: http://kerrybenninghoff.com/Newsltem.aspx? NewsID=4495. Accessed June 12, 2010.

\begin{tabular}{|c|c|}
\hline Year 1 & Year 2 \\
\hline Identified key stakeholders & $\begin{array}{l}\text { Developed age-specific, ethnically } \\
\text { diverse, KIHC brochures }\end{array}$ \\
\hline Formed advisory board & $\begin{array}{l}\text { Participated in } 2 \text { community } \\
\text { hospital-sponsored health fairs }\end{array}$ \\
\hline $\begin{array}{l}\text { Participated in a hospital } \\
\text { expo }\end{array}$ & $\begin{array}{l}\text { Visited } 22 \text { middle \& high schools } \\
\text { promoting KIHC activities }\end{array}$ \\
\hline $\begin{array}{l}\text { Participated in a } \\
\text { multi-county } \\
\text { healthvcareer fair }\end{array}$ & $\begin{array}{l}\text { Participated in a Lions Club-sponsored } \\
\text { youth health careers seminar }\end{array}$ \\
\hline $\begin{array}{l}\text { Participated in } 1 \text { middle } \\
\text { school health career fair }\end{array}$ & $\begin{array}{l}\text { Participated in a hospital expo for children } \\
\text { in pre-kindergarten through second } \\
\text { grade }\end{array}$ \\
\hline $\begin{array}{l}\text { Participated in a university } \\
\text { health fair }\end{array}$ & $\begin{array}{l}\text { Served as a member of a high school } \\
\text { health professions curriculum advisory } \\
\text { board committee }\end{array}$ \\
\hline $\begin{array}{l}\text { Participated in a } \\
\text { community } \\
\text { hospital-sponsored }\end{array}$ & $\begin{array}{l}\text { Collaborated with } 3 \text { Pennsylvania AHECS } \\
\text { to expand outreach to additional } \\
\text { counties }\end{array}$ \\
\hline health fair & $\begin{array}{l}\text { Acceptance of KIHC brochures and } \\
\text { materials into the Pennsylvania TEACH } \\
\text { program } \\
\text { Attended the Pennsylvania Rural Health } \\
\text { A5sociation Third Legislative Briefing }\end{array}$ \\
\hline
\end{tabular}

